Baseline

\title{
Distributions, sources and ecological risk assessment of arsenic and mercury in the surface sediments of the southwestern coastal Laizhou Bay, Bohai Sea
}

\author{
Wen Zhuang a,b, Xuelu Gao ${ }^{\text {a,* }}$ \\ ${ }^{a}$ Key Laboratory of Coastal Environmental Processes and Ecological Remediation, Yantai Institute of Coastal Zone Research, Chinese Academy of Sciences, Yantai, Shandong \\ 264003, China \\ ${ }^{\mathrm{b}}$ College of City and Architecture Engineering, Zaozhuang University, Zaozhuang, Shandong 277160, China
}

\section{A R T I C L E I N F O}

\section{Article history:}

Received 12 April 2015

Revised 15 July 2015

Accepted 17 July 2015

Available online 21 July 2015

\section{Keywords:}

Heavy metal

Sediment quality

Coastal environment

Ecological risk

Laizhou Bay

\begin{abstract}
A B S T R A C T
The spatial distributions of As and $\mathrm{Hg}$ in riverine and marine surface sediments of the coastal southwestern Laizhou Bay were obtained, and multiple indices and guidelines were applied to assess their contamination and ecological risks. The As concentrations in riverine sediments were close to those in marine sediments, and on the whole the dominant proportion of As was identified to be from natural sources. The Hg concentrations in riverine sediments were much higher than those in marine sediments, so river transportation was likely the main way of $\mathrm{Hg}$ into the southwestern Laizhou Bay. In respect of As, the sediment quality was fine according to the risk assessment methods used; in contrast, $\mathrm{Hg}$ presented an extremely contaminated status with a very high ecological risk in some riverine sediments, while most of the marine sediments were relatively much less polluted by $\mathrm{Hg}$ and under a lower ecological risk from it.
\end{abstract}

(c) 2015 Elsevier Ltd. All rights reserved.
There is worldwide concern about contamination caused by heavy metals such as arsenic (As) and mercury $(\mathrm{Hg})$, because of the environmental persistence, the biogeochemical recycling and the ecological risks of these elements. Untreated or not fully treated waste waters containing As and $\mathrm{Hg}$ from urban areas, industrial sites and agricultural areas are discharged into aquatic environments (Gao et al., 2014; Bastami et al., 2015; Zalewska et al., 2015). As and Hg are highly toxic heavy metals, which are transported in the water column, accumulated in sediments, and biomagnified through the food chain, resulting in remarkable ecological risks to benthic organisms, fish and humans (Neff, 1997; Mason et al., 2000; Cotin et al., 2011; Nance et al., 2012). When entering the aquatic environment, only a small part of free metal ions stay dissolved in water because of the combined action of adsorption, hydrolysis and co-precipitation, and the rest of them get deposited in sediments (Gaur et al., 2005). However, when environmental conditions change, sediments may transform from the main sink of heavy metals to the sources of them for the overlying waters (Gaur et al., 2005; Prica et al., 2008). So the

* Corresponding author at: Key Laboratory of Coastal Environmental Processes and Ecological Remediation, Yantai Institute of Coastal Zone Research, Chinese Academy of Sciences, 17 Chunhui Road, Yantai, Shandong 264003, China.

E-mail address: xlgao@yic.ac.cn (X. Gao). measurements of heavy metals only in the water and in the suspended materials are far from enough due to water discharge fluctuations and low resident time (Varol, 2011). Therefore the concentrations of heavy metals in sediments are often monitored to provide basic information for the environmental risk assessment (Long et al., 1995; SEPA, 2002).

The Laizhou Bay is a semi-enclosed shallow coastal water region located in the northwest of Shandong Peninsula with $\sim 7000 \mathrm{~km}^{2}$ in area and a $\sim 320 \mathrm{~km}$ long coastline, accounting for about $10 \%$ of the total area of the Bohai Sea, China. The Bohai Sea is recognized as one of the marine ecosystems in China that face with serious eco-environmental problems, and the Laizhou Bay is one of its three major bays (Gao et al., 2014). The topography of the Bay tilts from the southeast to the northwest, with a gradually down trend. Affected by the Yellow River, the Yellow River delta has been formed and increased year by year to the west bank of the Laizhou Bay. Affected by the surrounding rivers such as the Xiaoqinghe River, the Bailanghe River, the Weihe River, the Jiaolaihe River and so on, sediments in the southern and eastern coastal Bay consist of silt and sand; sediments in the northwestern coastal Bay were mainly clay and silt (Qiao et al., 2010; Hu et al., 2011; Zhuang and Gao, 2013, 2014a, 2014b). Due to the strong accumulation, the sea floor of the Laizhou Bay slopes gently, and there are many sea-bottom plains and shoals. The Laizhou Bay is 
the spawning and hatching place for many marine creatures, and it is also one of the most important aquaculture and fishing places in China.

Since the 1970s, with the booming of industry, agriculture, oil and gas industry, and marine transportation, the Laizhou Bay has been under serious pollution and ecological environment threats. The biggest threat comes from a chemical industry area on the southern shore, followed by the dotted small and medium-sized saltworks, chloralkali plants and marine aquacultures. Marine oil wells and oil platforms are also in or near to the Laizhou Bay. Besides, a large amount of upstream industrial wastewaters and domestic wastewaters carried by rivers such as the Xiaoqinghe River are discharged into the Laizhou Bay. These are all likely to cause As and $\mathrm{Hg}$ pollution to the environment.

An investigation of the surface sediment quality and the geochemical behaviors of trace elements was carried out in the southwestern coastal Laizhou Bay in 2012, covering its infralittoral zone and the lowermost areas of the major rivers to which it connects, and related papers have been published concerning the results of that investigation (Zhuang and Gao, 2013, 2014a; Gao et al., 2015). The objectives of this work were to quantify and explore the spatial distribution characteristics of As and $\mathrm{Hg}$ in the surface sediments of the southwestern coastal Laizhou Bay and evaluate the ecological risk of As and $\mathrm{Hg}$ to the surrounding areas.

The field sampling work of this research was carried out twice in 2012: early summer (May-June, hereafter referred to as summer for short), which was before the peak period of the rainy season, and middle autumn (September-October, hereafter referred to as autumn for short), which was after the peak period of the rainy season. The sampling sites were arranged along the major rivers of this area extending from the land to the sea and formed five transects, covering about $15-20 \mathrm{~km}$ from the high tide mark to the land and about $10 \mathrm{~km}$ from the high tide mark to the sea (Fig. 1; Zhuang and Gao, 2013; Gao et al., 2015). A total of 53 surface sediment samples (top $\sim 5 \mathrm{~cm}$ ) were collected in summer and 51 were collected in autumn (samples from sites MH3 and YHH2 were not collected in autumn because these two sites were unreachable), among which 18 marine samples were from the same sites in both sampling periods (Fig. 1). The riverine surface sediments were collected using a plastic spatula from the shallow water near to the riverside, and the marine surface sediments were collected with a stainless steel grab sampler. The samples used in this study were placed in acid cleaned polyethylene bags, and stored in a cooler box with ice bags immediately after collection. When taken back to the lab, the samples were stored at $\sim 4{ }^{\circ} \mathrm{C}$ in the dark until analyses were made.

An aliquot of each freeze-dried, homogenized and ground sample was digested with the mixture of concentrated $\mathrm{HF}, \mathrm{HNO}_{3}$ and $\mathrm{HClO}_{4}$ (5:2:1) (Gao et al., 2010). Then, hydride generation atomic fluorescence spectrometry (SK-2002A) was applied to the determination of $\mathrm{As}$ and $\mathrm{Hg}$ in the acid digested samples, and inductively coupled plasma optical emission spectrometry (PerkinElmer Optima 7000 DV) was applied to the determination of Al, Fe and Mn.

Analytical methods and results of the total organic carbon (TOC), grain size and moisture content of the samples have been described in our previous publications (Zhuang and Gao, 2013, 2014a, 2014b; Zhuang et al., 2014). The substance concentrations in the sediments were expressed on the dry weight basis based on the results of moisture content.

The analytical data quality was guaranteed through the implementation of laboratory quality assurance and quality control methods, including the use of standard operating procedures, calibration with standards, analysis of reagent blanks, and analysis of replicates. The precision of the analysis of standard solution (RSD) was better than 5\%. All analyses were carried out in duplicate, and the results were expressed as the mean. The quality of the analytical procedures was tested by recovery measurements on the Chinese national geostandard samples (GBW-07333 and GBW-07314). The results were consistent with the reference values, and the differences were all within $\pm 10 \%$. All reagents were guaranteed grade or higher level. All the labwares (bottles, tubes, etc.) were pre-cleaned by soaking in $10 \% \mathrm{HNO}_{3}(\mathrm{w} / \mathrm{w})$ for at least two days, followed by soaking and rinsing with de-ionized water.

The spatial distribution of As and $\mathrm{Hg}$ is shown in Fig. 2 and the related information is summarized in Table 1 . The mean concentration of As in the marine sediments was a little lower than that in the riverine sediments in both summer and autumn. In general, the relatively higher concentrations of As were found mainly in several riverine sites in the Yihonghe, the Guanglihe, the Zhimaihe, the Xiaoqinghe and the Mihe Rivers, and the highest value was recorded in site GLH3 $\left(22.88 \mu \mathrm{g} \mathrm{g}^{-1}\right.$, summer). These sites were closer to urban area or chemical industries which are more affected by extensive human activities. Whereas the As concentrations in sites of the Bailanghe, the Yuhe and the Dihe Rivers were obviously lower than those in the marine areas adjacent to

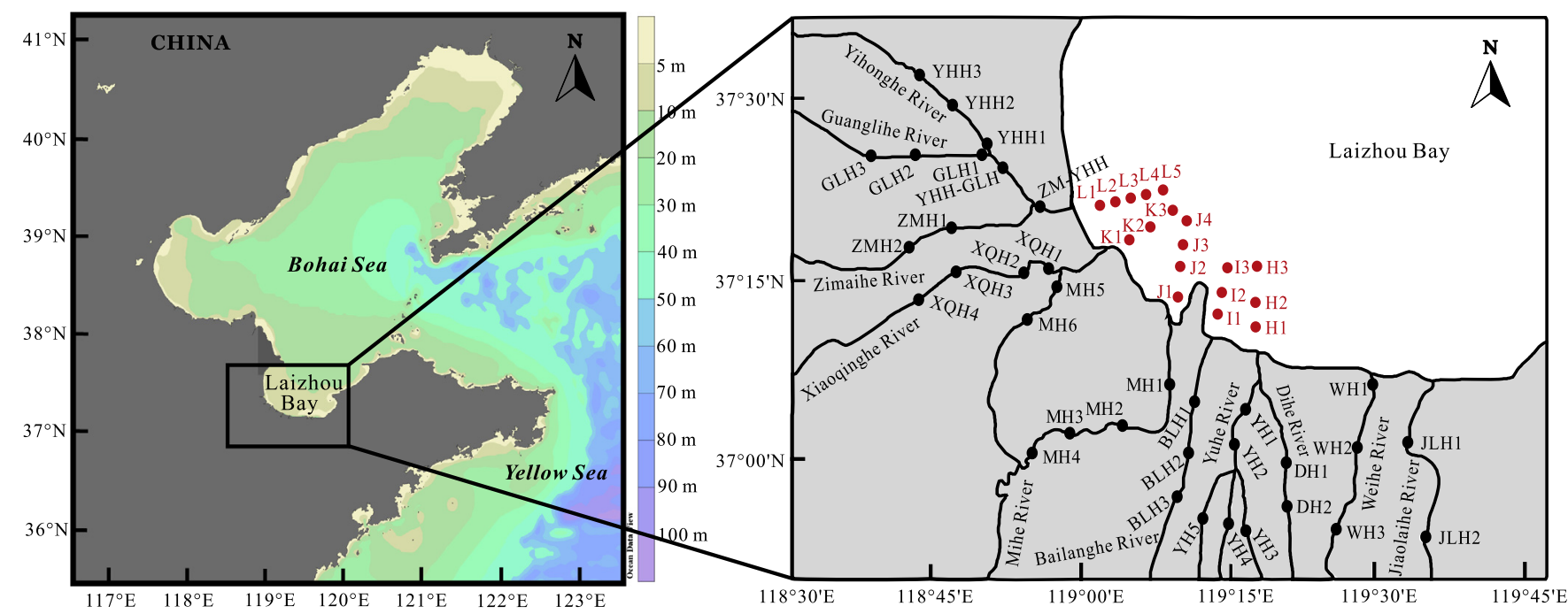

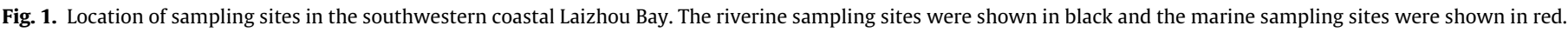
(For interpretation of the references to color in this figure legend, the reader is referred to the web version of this article.) 

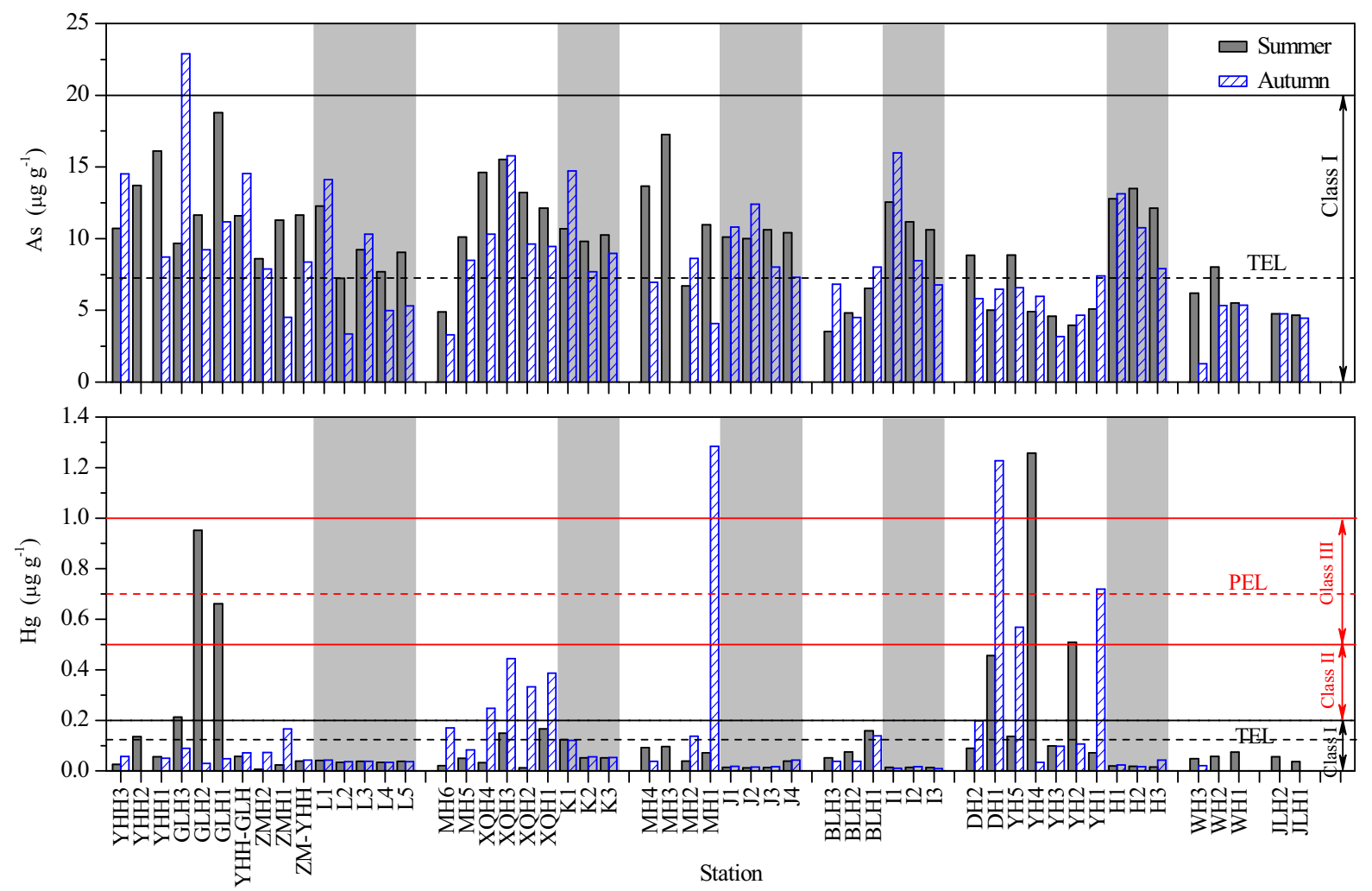

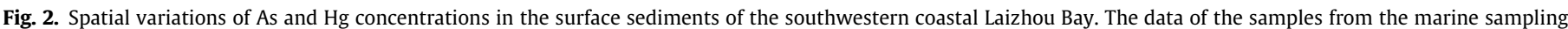

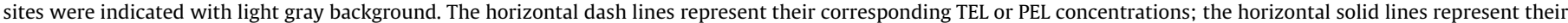
corresponding higher boundary values of Class I to III sediment categories of China.

Table 1

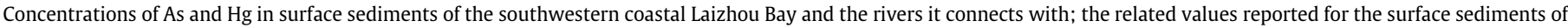
other marine areas, the SQGs and soil of Shandong Province are shown for comparison. Concentration unit is $\mu \mathrm{g} \mathrm{g}^{-1}$ for both As and Hg.

\begin{tabular}{|c|c|c|c|c|c|c|}
\hline & & Sampling date & & As & $\mathrm{Hg}$ & References \\
\hline \multirow[t]{17}{*}{ Location } & $\begin{array}{l}\text { Rivers in SW coastal Laizhou Bay (Bohai Sea), } \\
\text { China }\end{array}$ & May-June, 2012 & Range & $3.5-18.8$ & $<0.01-1.26$ & Present study \\
\hline & & & Mean & 9.4 & 0.17 & \\
\hline & & $\begin{array}{l}\text { September-October, } \\
2012\end{array}$ & Range & $1.3-22.9$ & $<0.01-1.28$ & \\
\hline & & & Mean & 7.9 & 0.21 & \\
\hline & $\begin{array}{l}\text { Coastal waters in SW Laizhou Bay (Bohai Sea), } \\
\text { China }\end{array}$ & May-June, 2012 & Range & $7.2-13.5$ & $0.01-0.12$ & Present study \\
\hline & & & Mean & 10.6 & 0.03 & \\
\hline & & $\begin{array}{l}\text { September-October, } \\
2012\end{array}$ & Range & $3.4-16.0$ & $<0.01-0.12$ & \\
\hline & & & Mean & 9.5 & 0.04 & \\
\hline & Intertidal Laizhou Bay (Bohai Sea), China & July, 2013 & Mean & 7.1 & 0.039 & Zhang and Gao (2015) \\
\hline & Laizhou Bay (Bohai Sea), China & August, 2007 & Mean & 13.1 & 0.053 & Hu et al. (2011) \\
\hline & Laizhou Bay (Bohai Sea), China & May, 2008 & Mean & 9.2 & 0.09 & Luo et al. (2010a) \\
\hline & Liaodong Bay (Bohai Sea), China & August, 2007 & Mean & 8.3 & 0.04 & Hu et al. (2010) \\
\hline & Northern Bohai and Yellow Seas, China & October 2008 & Mean & 8.5 & 0.028 & Luo et al. (2010b) \\
\hline & Jade Bay (North Sea), Germany & $2009-2010$ & Mean & 8 & na & Beck et al. (2013) \\
\hline & İzmit Bay (Marmara Sea), Turkey & April, 2002 & Mean & 21.9 & na & $\begin{array}{l}\text { Pekey and Doğan } \\
\text { (2013) }\end{array}$ \\
\hline & Gironde Estuary (French Atlantic coast), France & na & Mean & 18.7 & 0.16 & Larrose et al. (2010) \\
\hline & San Francisco Bay (Western Pacific coast), USA & $\begin{array}{l}\text { March, 2000-March, } \\
2001\end{array}$ & Mean & na & 0.17 & Lu et al. (2005) \\
\hline $\begin{array}{l}\text { Background value in } \\
\text { soil of Shandong } \\
\text { Province }\end{array}$ & & & & 9.3 & 0.019 & CNEMC (1990) \\
\hline \multirow[t]{5}{*}{ SQGs } & Class I upper limit & & & 20 & 0.2 & SEPA (2002) \\
\hline & Class II upper limit & & & 65 & 0.5 & \\
\hline & Class III upper limit & & & 93 & 1 & \\
\hline & TEL guideline & & & 7.3 & 0.13 & $\begin{array}{l}\text { MacDonald et al. } \\
\text { (1996) }\end{array}$ \\
\hline & PEL guideline & & & 41.6 & 0.7 & \\
\hline
\end{tabular}

na: not available. 
them, and the lowest value was recorded in site WH3 $\left(1.27 \mu \mathrm{g} \mathrm{g}^{-1}\right.$, summer), indicating As in the surface sediments of their connected inshore area might be a result of hydrodynamic transport from the surrounding sea region rather than from riverine discharge.

The concentrations of $\mathrm{Hg}$ in the marine sediments were much lower than those in the riverine sediments in both seasons, showing the sources of $\mathrm{Hg}$ were mainly of land-based activities. The highest concentration of $\mathrm{Hg}$ was recorded in site $\mathrm{MH} 1\left(1.28 \mu \mathrm{g} \mathrm{g}^{-1}\right.$, summer); the relatively higher concentrations were found mainly in the Guanglihe, the Xiaoqinghe, the Dihe, the Yuhe and the Mihe Rivers, and the most likely sources were the factory discharge and the burning of fossil fuels.

On the whole, the mean concentrations of both As and $\mathrm{Hg}$ in the marine sediments in this study were comparable to their corresponding mean values reported for surface sediments of the Chinese coastal seas that were listed in Table 1 . The mean concentrations of As in the studied area were a little higher with respect to its corresponding mean value in surface sediments of the Jade Bay in Germany, and were far lower with respect to its corresponding mean values in surface sediments of the İzmit Bay in Turkey and the Gironde Estuary in France (Table 1). The mean concentrations of $\mathrm{Hg}$ were far lower with respect to its corresponding mean values in surface sediments of the Gironde Estuary in France and the San Francisco Bay in USA as listed in Table 1.

To seek the relationships of As and $\mathrm{Hg}$ between the two sampling periods, scatter graphs were made for their concentrations (Fig. 3). There was a significant correlation $\left(P=3.7 \times 10^{-5}\right)$ between the concentrations of As in summer and the corresponding concentrations in autumn, indicating that their sources in the studied area were similar in different seasons, which might be mainly from natural sources. While reflected by the slope (0.64) and intercept (2.35) of the linear regression equation in Fig. 3, the emission intensity of sources between the two seasons was different to some extent. Discharge intensity, rainfall water, hydrodynamic conditions were all possible factors that cause this phenomenon.

There was no significant correlation $(P=0.64)$ between the concentrations of $\mathrm{Hg}$ in summer and the corresponding concentrations in autumn, showing that there was a huge difference between their sources in different seasons. This result indicated that $\mathrm{Hg}$ was derived from a wealth of sources, which might include thermal power plant, agriculture, factory discharges, consumer products and urban runoff, with strong randomness in their emission intensity.

The correlation matrix for the concentrations of the geochemical parameters studied is shown in Table 2. As and Hg had no significant correlation in the two seasons, indicating the sources of them had a big difference. As had significant correlations with Al and Fe, showing that it mainly came from terrigenous detrital. The significant correlations between As and $\mathrm{Mn}$ indicated that As was controlled by Mn oxide. $\mathrm{Hg}$ had no significant correlation with $\mathrm{Al}$, Fe or $\mathrm{Mn}$, further illustrating $\mathrm{Hg}$ had obviously different sources from As.

It has been reported that the deposition of fine grained materials and organic matters physically controls the abundance and distribution of metals in sediments (Gomes et al., 2009). In summer, As was significantly correlated with TOC; and As and $\mathrm{Hg}$ were both significantly and positively correlated with fine fractions (clay and/or silt) in this season. But in autumn, both As and $\mathrm{Hg}$ were not correlated with fine fractions, and their distribution might be mainly controlled by sewage discharge and atmospheric precipitation (Luo et al., 2010a; Hu et al., 2011). After the rainy season, various sorts of pollutants were discharged into the water environment, combined with the uncertainty of the intensity of human activities, and finally caused the differences between correlation analysis results of the two seasons. This result was similar with the study about the geochemical characteristics of heavy metals in the surface sediment of the Yellow River Estuary (Wu et al., 2013).

Studies have shown that the ratio of $\mathrm{Fe}$ and $\mathrm{Al}$ can be used to determine the migration pathways of terrigenous detrital, such as taken by rivers or dust (Taylor and McLennan, 1985; Pye, 1987). The average $\mathrm{Fe} / \mathrm{Al}$ ratios in atmospheric dust, riverine sediment and hydrotherm are $0.28,0.84$ and 1.61 , respectively (Taylor and McLennan, 1985; Pye, 1987). In the marine surface sediments of the Laizhou Bay in summer and autumn, the scopes of Fe/Al ratio were $0.32-0.42$ and $0.34-0.47$, respectively, with the averages of 0.37 and 0.40 , respectively. This result showed that As and $\mathrm{Hg}$ in the Laizhou Bay came from the combined action of dust and riverine sediments.

Marine Sediment Quality of China (SEPA, 2002) is one of the sediment quality guidelines (SQGs) usually used as a general measure of marine sediment contamination in China; TEL (threshold effects level) and PEL (probable effects level) were also proved to be effective sediment quality guidelines (Long et al., 2000; Sundaray et al., 2011). So these guidelines were chosen in this study. The higher boundary values of marine sediment quality of China and the corresponding TEL and PEL concentrations were listed in Table 1 and marked in Fig. 2.

Most of the sites exceeded the TEL guideline for As. The two sites in the Jiaolaihe River in both seasons were lower than the TEL guideline for As; the Bailanghe River was also in good condition, only the site BLH1 near the river mouth was a little higher than TEL guideline for As. Only As in site GLH3 in autumn exceeded the upper limit of marine sediment quality of China Class I (Fig. 2). This site was located in the urban area of the Dongying City, and
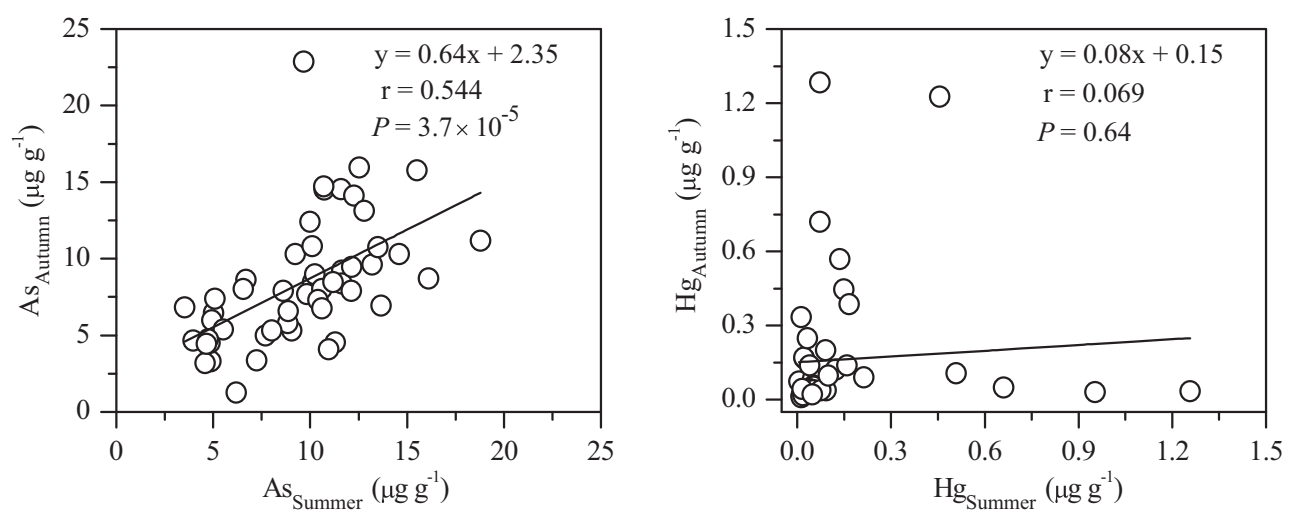

Fig. 3. Relationships between the summer and autumn data of As (left) and $\mathrm{Hg}$ (right) in the surface sediments of the southwestern coastal Laizhou Bay. 
Table 2

Pearson correlation matrix for As/Hg and environmental parameters in surface sediments ( $n=53$ for summer, $n=51$ for autumn).

\begin{tabular}{|c|c|c|c|c|c|c|c|c|c|c|}
\hline & & As & $\mathrm{Hg}$ & $\mathrm{Al}$ & $\mathrm{Fe}$ & Mn & \%TOC & \%Clay & \%Slit & \%Sand \\
\hline \multirow[t]{2}{*}{ Summer } & As & 1 & -0.069 & $0.437^{a}$ & $0.568^{\mathrm{a}}$ & $0.331^{c}$ & $0.399^{\mathrm{b}}$ & $0.294^{c}$ & $0.313^{c}$ & $-0.325^{c}$ \\
\hline & $\mathrm{Hg}$ & & 1 & 0.152 & 0.123 & -0.205 & -0.004 & $0.362^{b}$ & 0.155 & -0.216 \\
\hline \multirow[t]{2}{*}{ Autumn } & As & 1 & -0.074 & $0.572^{\mathrm{a}}$ & $0.517^{a}$ & $0.374^{b}$ & 0.018 & 0.196 & 0.237 & -0.236 \\
\hline & $\mathrm{Hg}$ & & 1 & -0.067 & -0.001 & -0.070 & 0.134 & 0.031 & -0.024 & 0.013 \\
\hline
\end{tabular}

\footnotetext{
a $P<0.001$.

b $0.001<P<0.01$.

c $0.01<P<0.05$.
}

the relatively high level of As concentration in the surface sediment of this site might be due to the influence of anthropogenic activities. In general, As concentration is low in the surface sediments of the studied area, and toxic effects may occur occasionally in riverine sediments.

In the marine areas, except for the site $\mathrm{K} 1$ in which $\mathrm{Hg}$ concentration was near the TEL value, all the values in the other sites were far below the TEL value for $\mathrm{Hg}$. No $\mathrm{Hg}$ value of the marine sites exceeded the upper limit for Class I sediment of China. Hg pollution in parts of the Guanglihe, the Mihe, the Dike and the Yuhe Rivers was relatively serious. $\mathrm{Hg}$ values exceeded the PEL value in GLH2 and YH4 in summer, and in MH1, DH1 and YH1 in autumn. Compared with the marine sediment quality of China, $\mathrm{Hg}$ in site YH4 in summer and in MH1 and DH1 in autumn exceeded the upper limit for Class III sediment, showing extremely serious pollution caused by $\mathrm{Hg}$.

The Guanglihe River flows through the Dongying City, so As and $\mathrm{Hg}$ in sediments were likely from point sources such as industrial wastewater and sewage (Zhang et al., 2013) and nonpoint sources such as coal ash and automobile exhaust (Luo et al., 2010b; Fujita et al., 2014). The Mihe and the Yuhe Rivers flow through the Weifang Binhai Economic Development Zone which is one of the largest brine chemical industry bases in China, so the high values of $\mathrm{Hg}$ and As in some sites of these rivers were caused by the discharge of the surrounding factories and transportation.

Geoaccumulation index $\left(I_{\text {geo }}\right)$ is a contamination index which is defined by the following equation:

$I_{\text {geo }}=\log _{2}\left(\frac{C_{n}}{1.5 B_{n}}\right)$

where $C_{n}$ is the measured concentration of metal $n ; B_{n}$ is the geochemical background concentration of metal $n$. Correction index 1.5 is usually used to characterize the sedimentary and geological characteristics of rocks and other effects (Varol, 2011). According to the recently published literature of Xu et al. (2015), sediment in the Laizhou Bay was primarily from the material discharged by rivers along its western and southern coasts. So, the background concentrations of As and $\mathrm{Hg}$ in soil of Shandong Province (Table 1 ) were adopted to calculate the $I_{\text {geo }}$ values in this research as that of Xu et al. (2015) did. The geoaccumulation index consists of seven classes: $I_{\text {geo }} \leqslant 0$ (Class 0 , practically uncontaminated); $0<I_{\text {geo }} \leqslant 1$ (Class 1 , uncontaminated to moderately contaminated); $1<I_{\text {geo }} \leqslant 2$ (Class 2 , moderately contaminated); $2<I_{\text {geo }} \leqslant 3$ (Class 3 , moderately to heavily contaminated); $3<I_{\text {geo }} \leqslant 4$ (Class 4 , heavily contaminated); $4<I_{\text {geo }} \leqslant 5$ (Class 5 , heavily to extremely contaminated); $5<I_{\text {geo }}$ (Class 6, extremely contaminated) (Müller, 1969).

As shown in Fig. 4, except for in a few sites, the $I_{\text {geo }}$ values of As in both seasons were less than 0 , showing that it was in a practically uncontaminated status in the study area. The $I_{\text {geo }}$ values indicated that $\mathrm{Hg}$ was in a practically uncontaminated status in most of the marine sites in the J, I and $\mathrm{H}$ transects and it was in an uncontaminated to moderately contaminated status in the remaining marine sites except $\mathrm{K} 1$; in comparison, $\mathrm{Hg}$ richly varied from a moderately contaminated status to an extremely contaminated status in more than half of the riverine sites at least in one season and it was in an uncontaminated to moderately contaminated status in most of the remaining riverine sites (Fig. 4).

Enrichment factor (EF) is a normalization technique frequently used to separate the metals of natural variability from the fraction that is associated with sediments due to anthropogenic activities (Gao and Chen, 2012). It is generally considered that an EF value of higher than 1.5 suggests that a significant portion of metal is delivered from non-crustal materials and the sources are more likely to be anthropogenic (Zhang and Liu, 2002). The EFs for As and $\mathrm{Hg}$ were calculated to evaluate anthropogenic influences on them in sediments using the following formula:

$$
\mathrm{EF}=\frac{\left(C_{\mathrm{X}} / C_{\mathrm{Al}}\right)_{\text {Sample }}}{\left(C_{\mathrm{X}} / C_{\mathrm{Al}}\right)_{\text {Background }}}
$$

where $C_{\mathrm{X}}$ and $C_{\mathrm{Al}}$ denote the concentrations of element $\mathrm{X}$ and $\mathrm{Al}$ in the samples and their background values. Similar to the $I_{\text {geo }}$ calculation, the corresponding concentrations of element $\mathrm{X}$ and $\mathrm{Al}$ in soil of Shandong Province (Table 1) were adopted as the background value. In this study, Al was used as the reference element for geochemical normalization because it represents the quantity of aluminosilicates which is generally the predominant carrier phase for metals in coastal sediments and its natural concentration tends to be uniform (Alexander et al., 1993).

The spatial distributions of calculated EFs of As and $\mathrm{Hg}$ are shown in Fig. 5. In both seasons, the EF values indicated that As was in a condition of no enrichment $(\mathrm{EF} \leqslant 1)$ or minor enrichment $(1<\mathrm{EF} \leqslant 3)$ in all sites. Except for in a few sites in one season or both seasons, the EF values of As were less than 1.5, indicating the dominance of natural origin. The EF values of $\mathrm{Hg}$ in almost all the marine sites in both seasons fell in a range of $1-3$, indicating a condition of minor enrichment; $\mathrm{Hg}$ was enriched in varying degrees in almost all the riverine sites, and very severe enrichment $(25<\mathrm{EF} \leqslant 50)$ and extremely severe enrichment $(\mathrm{EF}>50)$ of $\mathrm{Hg}$ were recorded in some sites in both seasons. The $\mathrm{EF}$ values of $\mathrm{Hg}$ in most of the marine sites in the J, I and $\mathrm{H}$ transects indicated a total of natural origin, while in most of the remaining marine sites a certain degree of anthropogenic contribution could be seen; in some of the riverine sites, anthropogenic contribution was the dominant source of $\mathrm{Hg}$ in one season or both seasons.

Potential ecological risk factor $\left(E_{r}^{i}\right)$ was originally developed by Håkanson (1980) and is an index widely used in ecological risk assessment of heavy metals in sediments. According to this methodology, the potential ecological risk index is defined as:

$E_{r}^{i}=T_{r}^{i} \times C_{f}^{i}=T_{r}^{i} \times\left(C_{o}^{i} / C_{n}^{i}\right)$

where $E_{r}^{i}$ is the potential ecological risk factor for a given element $i$; $T_{r}^{i}$ is the toxic-response factor for this element; $C_{f}^{i}, C_{o}^{i}$ and $C_{n}^{i}$ are the contamination factor, the concentration in the sediment and the background reference level for the element $i$, respectively. Like that of EF and $I_{\text {geo }}$ calculation, the corresponding background concentrations of As and $\mathrm{Hg}$ in soil of Shandong Province (Table 1) were adopted to calculate their $E_{r}^{i}$ values in this study. According to 

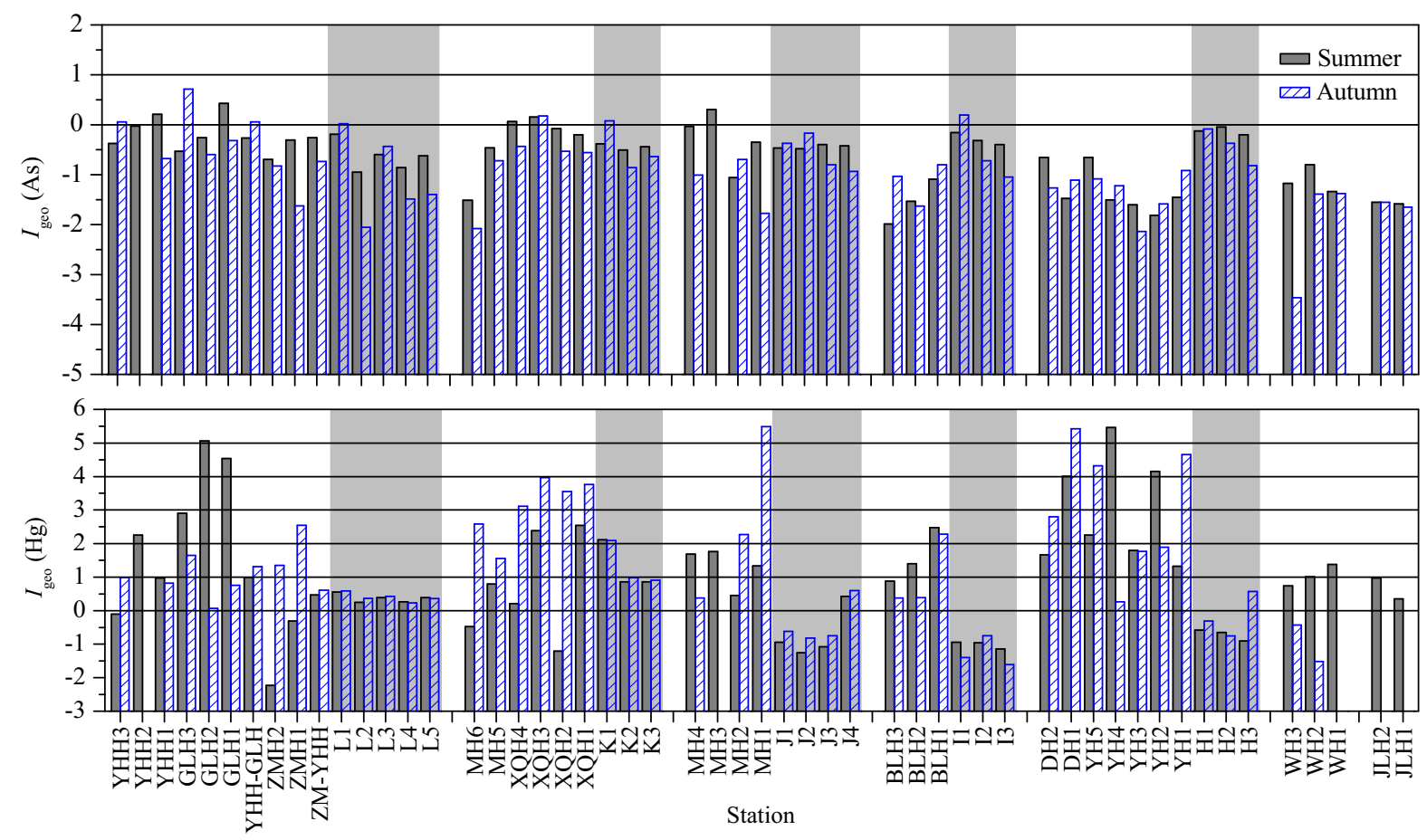

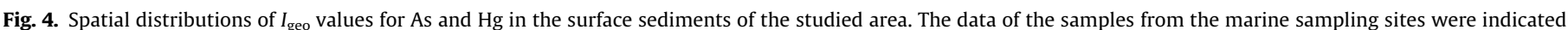

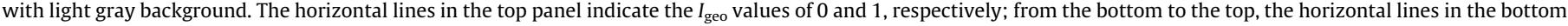
panel indicate the $I_{\text {geo }}$ values of $0,1,2,3,4$ and 5 , respectively.
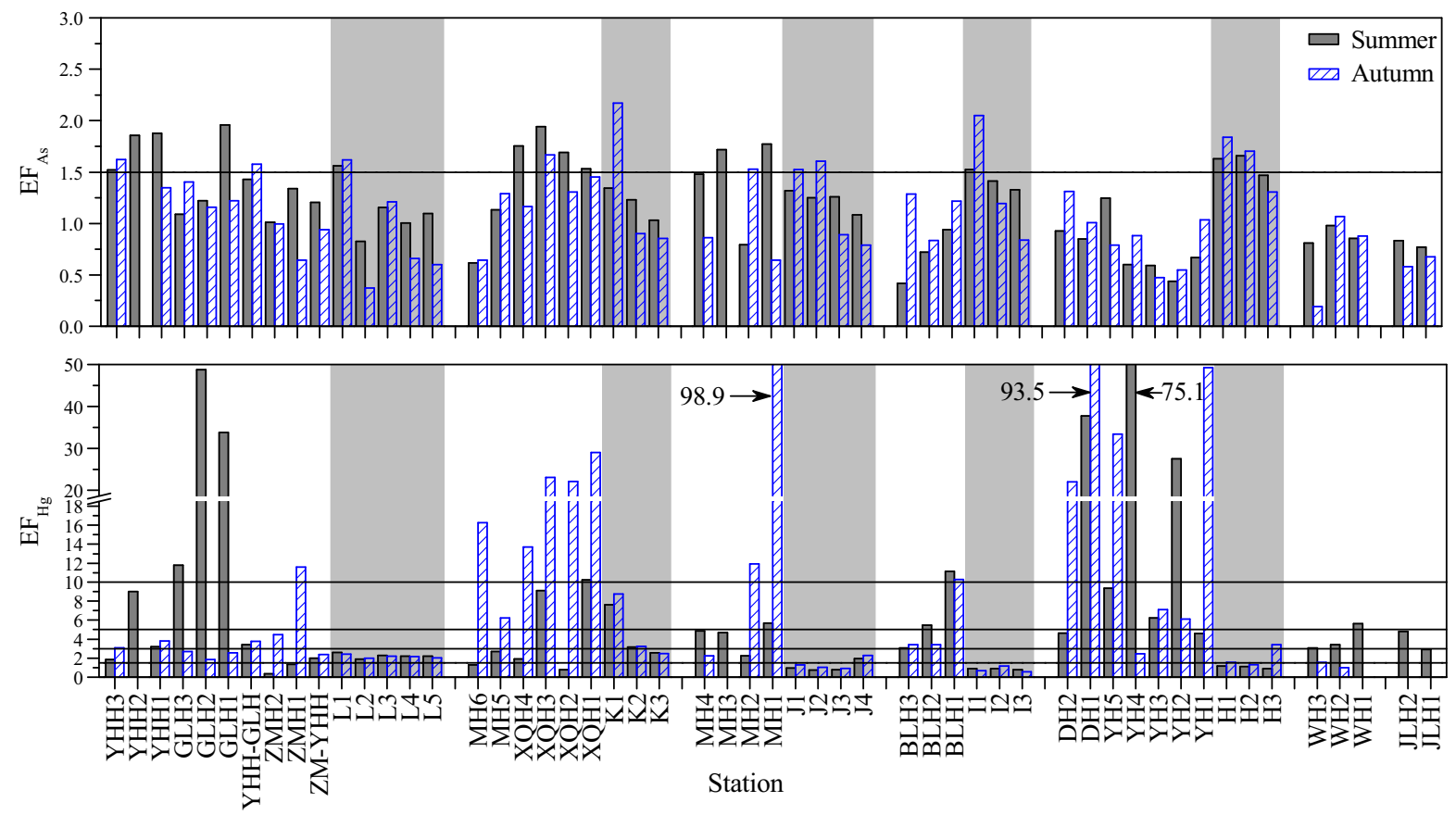

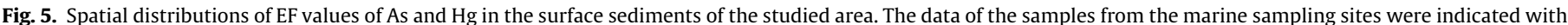

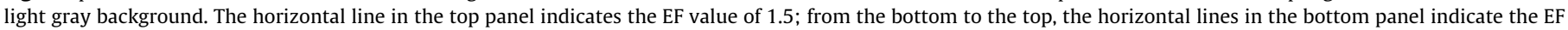
values of $1.5,3,5$ and 10 , respectively.

Håkanson (1980), $T_{r}$ is 10 for As and 40 for $\mathrm{Hg}$, and the following tiers are used for the classification of $E_{r}^{i}$ values of an element: (i) $E_{r}^{i} \leqslant 40$ (low risk); (ii) $40<E_{r}^{i} \leqslant 80$ (moderate risk); (iii) $80<E_{r}^{i} \leqslant 160$ (considerable risk); (iv) $160<E_{r}^{i} \leqslant 320$ (high risk); (v) $320<E_{r}^{i}$ (very high risk).

It was clearly reflected by the spatial distributions of the calculated $E_{r}^{i}$ s of As and $\mathrm{Hg}$ shown in Fig. 6 that $\mathrm{Hg}$ had a much higher potential ecological risk than As in almost all the riverine surface sediments of the studied area in both seasons. With the ranges of 3.8-20.2 in summer and 3.4-24.6 in autumn, the $E_{r}{ }^{\text {As }}$ results showed that As in all sites in both seasons had a low potential ecological risk. Although they were apparently higher than their corresponding $E_{r}{ }^{\text {As }}$ values, the $E_{r}^{\mathrm{Hg}}$ values in all the marine sites in the $\mathrm{J}$ and I transects except one were also lower than 40 in both seasons, 

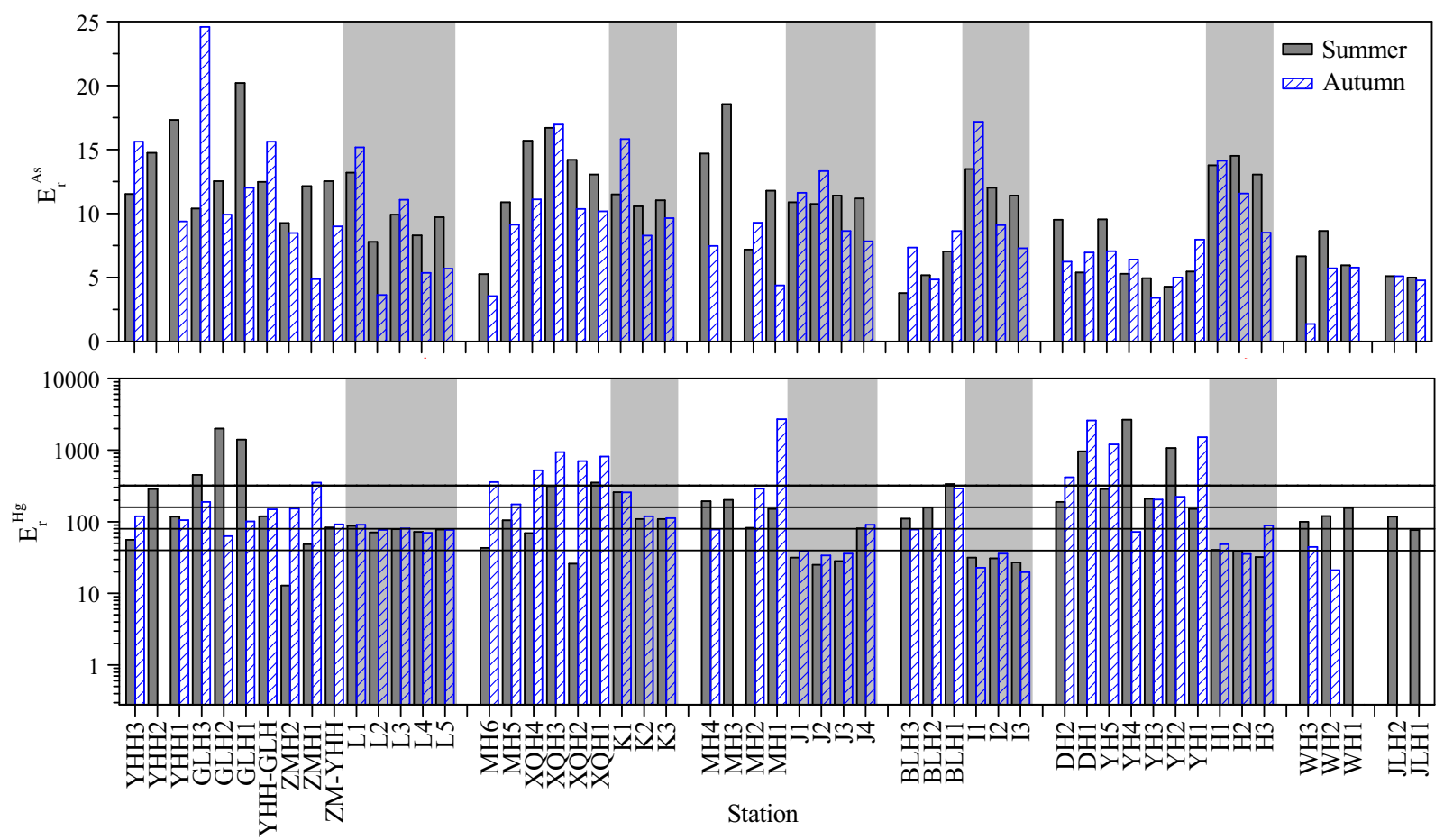

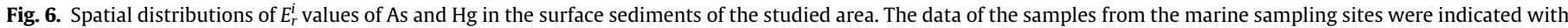

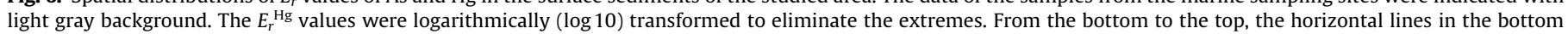
panel indicate the $E_{r}{ }^{\mathrm{Hg}}$ values of $40,80,160$ and 320 , respectively.

showing a low potential ecological risk; The $E_{r}{ }^{\mathrm{Hg}}$ values in most of the remaining marine sites fell in the ranges that indicate moderate and considerable ecological risks. The $E_{r}{ }^{\mathrm{Hg}}$ values in some riverine sites in one season or both seasons were far higher than 320 , showing a very high potential ecological risk; they fell in the ranges that indicate considerable and high ecological risks in most of the remaining riverine sites.

Environmental quality assessment related trace metals such as As and $\mathrm{Hg}$, which is better known to people as heavy metals, are accumulated in environments partly from natural sources and partly from human activities. Lithogenic part and non-lithogenic part of heavy metals in environments could be recognized broadly as the natural input and the non-natural input, respectively (Turekian and Wedepohl, 1961). The following formula was used for differentiating non-lithogenic from lithogenic As and $\mathrm{Hg}$ (Turekian and Wedepohl, 1961):

$\mathrm{X}_{\mathrm{NL}}=\mathrm{X}_{\text {total }}-\mathrm{X}_{\mathrm{L}}=\mathrm{X}_{\text {total }}-\left[\mathrm{Al}_{\text {total }} \times(\mathrm{X} / \mathrm{Al})_{\text {Background }}\right]$

where $\mathrm{X}$ is the target element. The lithogenic $\mathrm{X}\left(\mathrm{X}_{\mathrm{L}}\right)$ of each sample is the result of the measured total concentration of $\mathrm{Al}\left(\mathrm{Al}_{\text {total }}\right)$ times the $\mathrm{X} / \mathrm{Al}$ ratio of background; the non-lithogenic $\mathrm{X}\left(\mathrm{X}_{\mathrm{NL}}\right)$ was calculated as the difference between the total $\left(X_{\text {total }}\right)$ and lithogenic $X$ (Turekian and Wedepohl, 1961). This calculation assumed that all Al was of lithogenic origin rather than the result of scavenging or biogenic production (Duan et al., 2012). The corresponding background concentrations of $\mathrm{As}, \mathrm{Hg}$ and $\mathrm{Al}$ in soil of Shandong Province (Table 1) were adopted to calculate their non-lithogenic fractions. Results indicated that there was a very small amount of non-lithogenic As ranging from $\approx 0$ to $9.20 \mu \mathrm{g} \mathrm{g}^{-1}$ with a mean value of $2.34 \mu \mathrm{g} \mathrm{g}^{-1}$ accounting for $18.3 \%$ of its average total concentration in the samples in summer; in autumn, the corresponding data were from $\approx 0$ to $8.18 \mu \mathrm{g} \mathrm{g}^{-1}$ and $1.79 \mu \mathrm{g} \mathrm{g}^{-1}$ accounting for $14.9 \%$ of its average total concentration in the samples. The maximum values of $49.0 \%$ and $53.9 \%$ in summer and autumn were recorded in sites GLH1 and I1, respectively. There was a very large amount of non-lithogenic $\mathrm{Hg}$ ranging from $\approx 0$ to $1.24 \mu \mathrm{g} \mathrm{g}^{-1}$ with a mean value of $0.11 \mu \mathrm{g} \mathrm{g}^{-1}$ accounting for $57.3 \%$ of its average total concentration in the samples in summer; in autumn, the corresponding data were from $\approx 0$ to $1.27 \mu \mathrm{g} \mathrm{g}^{-1}$ and $0.15 \mu \mathrm{g} \mathrm{g}^{-1}$ accounting for $64.1 \%$ of its average total concentration in the samples. The maximum values of $98.7 \%$ and $99.0 \%$ in summer and autumn were recorded in sites $\mathrm{YH} 4$ and $\mathrm{MH} 1$, respectively. The results of non-lithogenic fraction of As and $\mathrm{Hg}$ corresponded well with the results of the $\mathrm{EF}$ analysis, indicating both of them are effective methods for the distinction between natural and anthropogenic sources.

In conclusion, this study indicated that, in the surface sediments of the SW coastal Laizhou Bay, the concentrations of $\mathrm{Hg}$ in riverine sediments were much higher than those in marine sediments, and high enrichment levels in some riverine spots were observed, so terrigenous sources especially human activities had important contribution to the distribution of $\mathrm{Hg}$ in this area. In contrast to that of $\mathrm{Hg}$, there was no significant difference in As concentrations between riverine sediments and marine sediments, and there was also no obvious enrichment of As. Thus, As was mainly from natural sources. Distribution of As was controlled by $\mathrm{Al}$, Fe and Mn oxides, but $\mathrm{Hg}$ was not. Deposition of fine grained materials and organic matters physically also controlled the abundance and distribution of As or $\mathrm{Hg}$ in summer; whereas the situation was more complicated in autumn because of the rainy season. The sedimentary condition of As was fine according to the marine sediment quality of China, and could have adverse effects occasionally according to TEL/PEL guideline. According to all the three risk assessment indices, pollution and ecological risk caused by As was at a very low level. Pollution and ecological risk caused by $\mathrm{Hg}$ was also at a very low level in marine sediments according to three risk assessment indices used, but heavy pollution and extremely high ecological risks were recorded in some riverine sediments. Pollution and ecological risk caused by $\mathrm{Hg}$ concentrated 
in the Guanglihe, the Xiaoqinghe, the Mihe, the Dihe and the Yuhe Rivers which have been suffering from intense human activities.

\section{Acknowledgements}

This study was co-supported by the National Natural Science Foundation of China (41376083) and the Natural Science Foundation of Shandong Province, China (ZR2014DP005). We thank Yong Zhang, Peimiao Li, Jinfeng Zhang and Fengxia Zhou who participated in the sample collection for their assistance.

\section{References}

Alexander, C.R., Smith, R.G., Calder, F.D., Schropp, S.J., Windom, H.L., 1993. The historical record of metal enrichments in two Florida estuaries. Estuaries 16, 627-637.

Bastami, K.D., Neyestani, M.R., Shemirani, F., Soltani, F., Haghparast, S., Akbari, A., 2015. Heavy metal pollution assessment in relation to sediment properties in the coastal sediments of the southern Caspian Sea. Mar. Pollut. Bull. 92, 237 243.

Beck, M., Böning, P., Schückel, U., Stiehl, T., Schnetger, B., Rullkötter, J., Brumsack, H.J., 2013. Consistent assessment of trace metal contamination in surface sediments and suspended particulate matter: a case study from the Jade Bay in NW Germany. Mar. Pollut. Bull. 70, 100-111.

CNEMC (China National Environmental Monitoring Center), 1990. Chinese Elemental Background Values for Soils. Chinese Environmental Science Press, Beijing.

Cotin, J., García-Tarrasón, M., Sanpera, C., Jover, L., Ruiz, X., 2011. Sea, freshwater or saltpans? Foraging ecology of terns to assess mercury inputs in a wetland landscape: the Ebro Delta. Estuar. Coast. Shelf Sci. 92 (1), 118-194.

Duan, L.Q., Song, J.M., Li, X.G., Yuan, H.M., Li, N., Xu, Y.Y., 2012. Thallium concentrations and sources in the surface sediments of Bohai Bay. Mar. Environ. Res. 73, 25-31.

Fujita, M., Ide, Y., Sato, D., Kench, P.S., Kuwahara, Y., Yokoki, H., Kayanne, H., 2014 Heavy metal contamination of coastal lagoon sediments: Fongafale Islet, Funafuti Atoll, Tuvalu. Chemosphere 95, 628-634.

Gao, X.L., Chen, C.T.A., 2012. Heavy metal pollution status in surface sediments of the coastal Bohai Bay. Water Res. 46, 1901-1911.

Gao, X.L., Chen, C.T.A., Wang, G., Xue, Q.Z., Tang, C., Chen, S., 2010. Environmental status of Daya Bay surface sediments inferred from a sequential extraction technique. Estuar. Coast. Shelf Sci. 86, 369-378.

Gao, X.L., Zhou, F.X., Chen, C.T.A., 2014. Pollution status of the Bohai Sea: an overview of the environmental quality assessment related trace metals. Environ. Int. 62, 12-30.

Gao, X.L., Zhuang, W., Chen, C.T.A., Zhang, Y., 2015. Sediment quality of the SW coastal Laizhou Bay, Bohai Sea, China: a comprehensive assessment based on the analysis of heavy metals. PLoS One 10 (3), e0122190. http://dx.doi.org/ 10.1371/journal.pone.0122190.

Gaur, V.K., Gupta, S.K., Pandey, S.D., Gopal, K., Misra, V., 2005. Distribution of heavy metals in sediment and water of River Gomti. Environ. Monit. Assess. 102, 419433.

Gomes, F., Godoy, J.M., Godoy, M.L., Carvalho, Z., Lopes, R., Sanchez-Cabeza, J.A., Lacerda, L., Wasserman, J., 2009. Metal concentrations, fluxes, inventories and chronologies in sediments from Sepetiba and Ribeira Bays: a comparative study. Mar. Pollut. Bull. 59, 123-133.

Håkanson, L., 1980. An ecological risk index for aquatic pollution control. A sedimentological approach. Water Res. 14, 975-1001.

Hu, N.J., Shi, X.F., Huang, P., Liu, J.H., 2010. Distribution of metals in surface sediments of Liaodong Bay, Bohai Sea. China Environ. Sci. 30 (3), 380-388 (In Chinese with English abstract).

Hu, N.J., Shi, X.F., Liu, J.H., Huang, P., Yang, G., Liu, Y.G., 2011. Distributions and impacts of heavy metals in the surface sediments of the Laizhou Bay. Adv. Mar. Sci. 29, 63-72 (In Chinese with English abstract).

Larrose, A., Coynel, A., Schäfer, J., Blanc, G., Massé, L., Maneux, E., 2010. Assessing the current state of the Gironde Estuary by mapping priority contaminant distribution and risk potential in surface sediment. Appl. Geochem. 25, 1912 1923.

Long, E.R., MacDonald, D.D., Smith, S.C., Calder, F.D., 1995. Incidence of adverse biological effects within ranges of chemical concentrations in marine and estuarine sediments. Environ. Manage. 19, 81-97.

Long, E.R., MacDonald, D.D., Severn, C.G., Hong, C.B., 2000. Classifying probabilities of acute toxicity in marine sediments with empirically derived sediment quality guideline. Environ. Toxicol. Chem. 19, 2598-2601.

Lu, X.Q., Werner, I., Young, T.M., 2005. Geochemistry and bioavailability of metals in sediments from northern San Francisco Bay. Environ. Int. 31, 593-602.
Luo, X.X., Zhang, R., Yang, J.Q., Liu, R.H., Tang, W., Yan, Q., 2010a. Distribution and pollution assessment of heavy metals in surface sediment in Laizhou Bay. Ecol. Environ. Sci. 19, 262-269 (In Chinese with English abstract).

Luo, W., Lu, Y.L., Wang, T.Y., Hu, W.Y., Jiao, W.T., Naile, J.E., Khim, J.S., Giesy, J.P., 2010b. Ecological risk assessment of arsenic and metals in sediments of coastal areas of northern Bohai and Yellow Seas, China. Ambio 39, 367-375.

MacDonald, D.D., Scottcarr, R., Calder, F.D., Long, E.R., Ingersoll, C.G., 1996. Development and evaluation of sediment quality guidelines for Florida coastal waters. Ecotoxicology 5, 253-278.

Mason, R.P., Laporte, J.M., Andres, S., 2000. Factors controlling the bioaccumulation of mercury, methylmercury, arsenic, selenium and cadmium by freshwater invertebrates and fish. Arch. Environ. Contam. Toxicol. 38 (3), 283-297.

Müller, G., 1969. Index of geoaccumulation in sediments of the Rhine River. GeoJournal 2, 108-118.

Nance, P., Patterson, J., Willis, A., Foronda, N., Dourson, M., 2012. Human health risks from mercury exposure from broken compact fluorescent lamps (CFLs). Regul. Toxicol. Pharmacol. 62 (3), 542-552.

Neff, J.M., 1997. Ecotoxicology of arsenic in the marine environment. Environ. Toxicol. Chem. 16 (5), 917-927.

Pekey, H., Doğan, G., 2013. Application of positive matrix factorisation for the source apportionment of heavy metals in sediments: a comparison with a previous factor analysis study. Microchem. J. 106, 233-237.

Prica, M., Dalmacija, B., Rončević, S., Krčmar, D., Bečelić, M., 2008. A comparison of sediment quality results with acid volatile sulfide (AVS) and simultaneously extracted metals (SEM) ratio in Vojvodina (Serbia) sediments. Sci. Total Environ. 389, 235-244.

Pye, K., 1987. Aeolian Dust and Dust Deposits. Academic Press, London, 334 pp.

Qiao, S.Q., Shi, X.F., Zhu, A.M., Liu, Y.G., Bi, N.S., Fang, X.S., Yang, G., 2010. Distribution and transport of suspended sediments off the Yellow River (Huanghe) mouth and the nearby Bohai Sea. Estuar. Coast. Shelf Sci. 86, 337344.

SEPA (State Environmental Protection Administration of China), 2002. Marine Sediment Quality (GB 18668-2002). Standards Press of China, Beijing.

Sundaray, S.K., Nayak, B.B., Lin, S., Bhatta, D., 2011. Geochemical speciation and risk assessment of heavy metals in the river estuarine sediments-a case study: Mahanadi basin, India. J. Hazard. Mater. 186, 1837-1846.

Taylor, S.R., McLennan, S.M., 1985. The Continental Crust: Its Composition and Evolution. Blackwell, Oxford, p. 312.

Turekian, K.K., Wedepohl, K.H., 1961. Distribution of the elements in some major units of the earth's crust. Geol. Soc. Am. Bull. 72, 175-192.

Varol, M., 2011. Assessment of heavy metal contamination in sediments of the Tigris River (Turkey) using pollution indices and multivariate statistical techniques. J. Hazard. Mater. 195, 355-364.

Wu, B., Song, J.M., Li, X.G., 2013. Environmental characteristics of heavy metals in surface sediments from the Huanghe Estuary. Environ. Sci. 34, 1324-1332 (In Chinese with English abstract).

Xu, G., Liu, J., Pei, S.F., Gao, M.S., Hu, G., Kong, X.H., 2015. Sediment Properties and Trace Metal Pollution Assessment in Surface Sediments of the Laizhou Bay. Environmental Science and Pollution Research, China. http://dx.doi.org/ 10.1007/s11356-015-4393-y.

Zalewska, T., Woroń, J., Danowska, B., Suplińska, M., 2015. Temporal changes in Hg, $\mathrm{Pb}, \mathrm{Cd}$ and $\mathrm{Zn}$ environmental concentrations in the southern Baltic Sea sediments dated with ${ }^{210} \mathrm{~Pb}$ method. Oceanologia $57,32-43$.

Zhang, J.F. Gao, X.L., 2015. Heavy metals in surface sediments of the intertidal Laizhou Bay, Bohai Sea, China: distributions, sources and contamination assessment. Mar. Pollut. Bull. 98, 320-327.

Zhang, J., Liu, C.L., 2002. Riverine composition and estuarine geochemistry of particulate metals in China-weathering features, anthropogenic impact and chemical fluxes. Estuar. Coast. Shelf Sci. 54, 1051-1070.

Zhang, R., Zhou, L., Zhang, F., Ding, Y.J., Gao, J.R., Chen, J., Yan, H.Q., Shao, W., 2013. Heavy metal pollution and assessment in the tidal flat sediments of Haizhou Bay, China. Mar. Pollut. Bull. 74 (1), 403-412.

Zhuang, W., Gao, X.L., 2013. Acid-volatile sulfide and simultaneously extracted metals in surface sediments of the southwestern coastal Laizhou Bay, Bohai Sea: concentrations, spatial distributions and the indication of heavy metal pollution status. Mar. Pollut. Bull. 76 (1-2), 128-138.

Zhuang, W., Gao, X.L., 2014a. Assessment of heavy metal impact on sediment quality of the Xiaoqinghe estuary in the coastal Laizhou Bay, Bohai Sea: inconsistency between two commonly used criteria. Mar. Pollut. Bull. 83 (1), 352-357.

Zhuang, W., Gao, X.L., 2014b. Integrated assessment of heavy metal pollution in the surface sediments of the Laizhou Bay and the coastal waters of the Zhangzi Island, China: comparison among typical marine sediment quality indices. PLoS One 9 (4), e94145. http://dx.doi.org/10.1371/journal.pone.0094145.

Zhuang, W., Gao, X.L., Zhang, Y., Xing, Q.G., Tosi, L., Qin, S., 2014. Geochemical characteristics of phosphorus in surface sediments of two major Chinese mariculture areas: the Laizhou Bay and the coastal waters of the Zhangzi Island. Mar. Pollut. Bull. 83 (1), 343-351. 